\title{
CHECK-LIST OF THE MOTHS OF SASKATCHEWAN PART 8: DAGGER-MOTHS (ACRONICTINAE) AND FORESTERS (AGARISTINAE)
}

RONALD R. HOOPER, Saskatchewan Museum of Natural History, 2340 Albert Street, Regina, Saskatchewan. S4P 3V7

Abbreviations: $\mathrm{s}=$ south, $\mathrm{n}=$ north, $\mathrm{w}=$ west, $\mathrm{e}=$ east, $\mathrm{CNC}=$ the only known Saskatchewan records of the species are in the Canadian National Collection in Ottawa. (Unless otherwise indicated all the species are represented in the collection of the Saskatchewan Museum of Natural History, Regina.)

\section{Dagger-Moths (Acronictinae)}

These are medium-sized to larger Owlet Moths (up to $55 \mathrm{~mm}$ in wing expanse). Near the lower corner of the fore-wing many species have a daggerlike black line. Many species also have a black basal streak on the fore-wing. Some species have the sub-marginal line of the fore-wing resembling the side profile of a human face. In such cases the reniform spot resembles an ear. Dagger-Moths usually live in wooded areas where they lay their eggs on various trees and shrubs. The pattern and colour on the fore-wings is constructed so as to cause the moth to blend amazingly well with the bark of the tree of the food plant. Because of this, the palest of our species have birch and aspen as their preferred food plants.

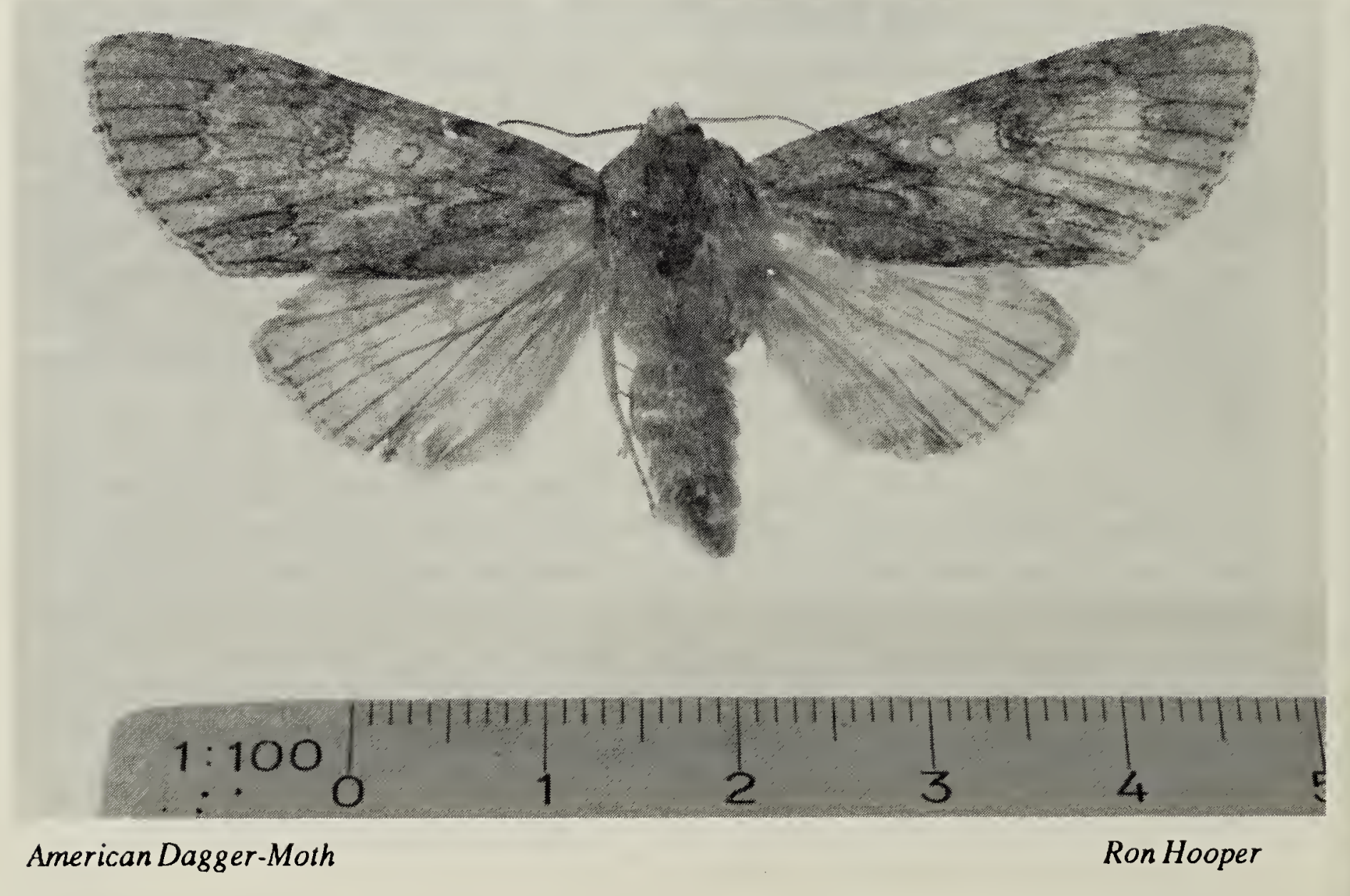



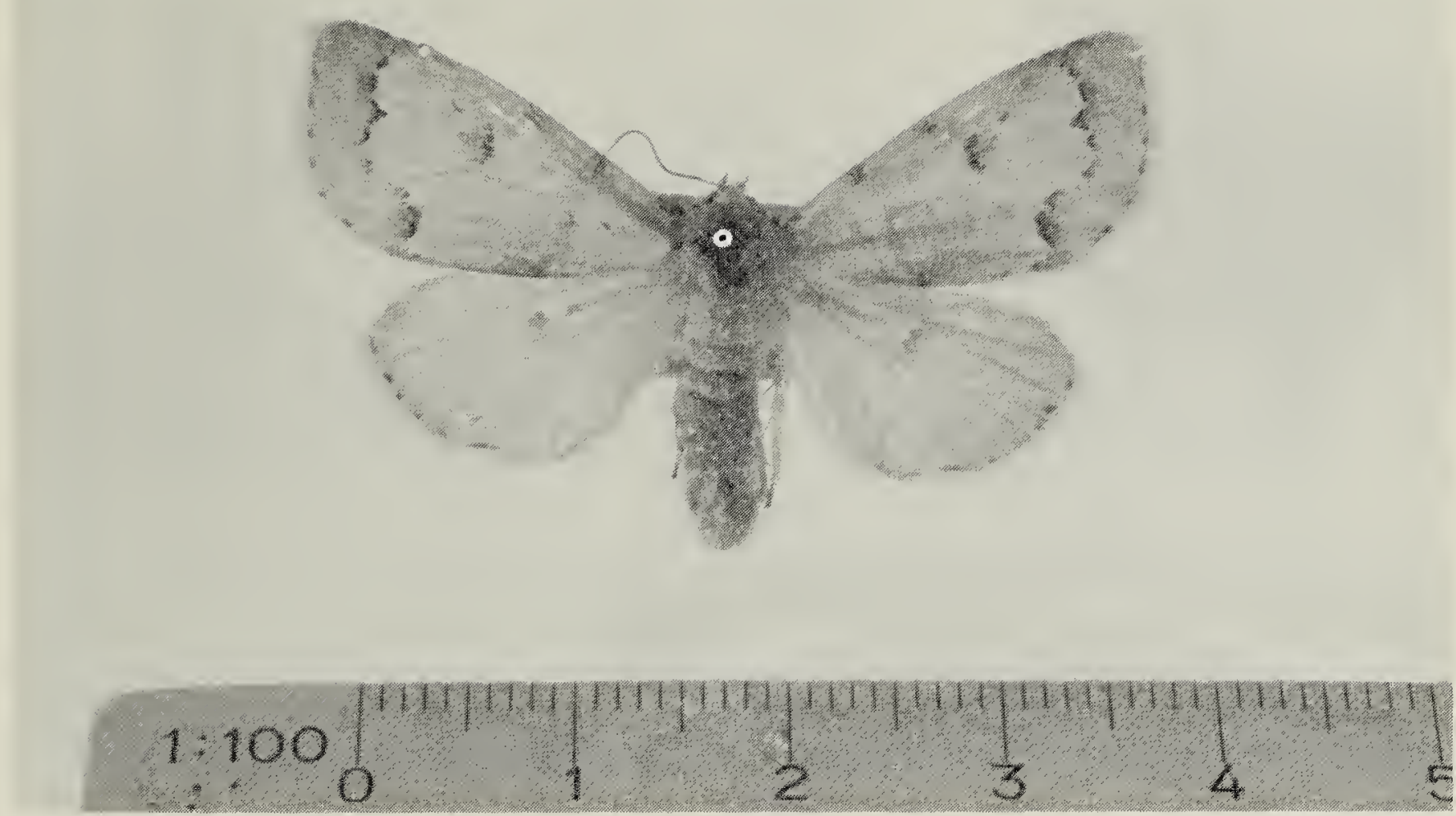

Unmarked Dagger-Moth

Ron Hooper

Dagger-Moths usually come more freely to sugar bait than they do to lights.

American Dagger-Moth - Acronicta americana (Harr.) - s Sask. $n$ to Erwood and Nipawin.

Fingered Dagger-Moth - Acronicta dactylina Grt. - s Sask. $\mathrm{n}$ to La Ronge.

Large Gray Dagger-Moth - Acronicta hesperida Sm. - Kamsack and Earl Grey.

Cottonwood Dagger-Moth - Acronicta lepusculina Gn. - s Sask. n to Nipawin Prov. Park.

Vulpina Dagger-Moth - Acronicta vulpina (Grt.) - s Sask. $\mathrm{n}$ to Cumberland House and Meadow Lake Prov. Park.

Unmarked Dagger-Moth - Acronicta innotata Gn. - $\mathrm{n}$ Sask. $\mathrm{s}$ to Moose Mountain and Fort Qu'Appelle.

Radcliffe's Dagger-Moth - Acronicta radcliffei (Harv.) - Cypress Hills, Fort Qu'Appelle, Hudson Bay and Nipawin.

Gray Dagger-Moth - Acronicta grisea Wlk. - s Sask. n to Sturgeon Landing, Otter Rapids and Porter Lake.

Gentle Dagger-Moth - Acronicta mansueta Sm. - Buffalo Pound Prov.
Park, and Rosefield (se of Val Marie).

Quadrate Dagger-Moth - Acronicta quadrata Grt. - s Sask. $\mathrm{n}$ to Fort Qu'Appelle and Battlefords Prov. Park.

Forked Dagger-Moth - Acronicta furcifera Gn. - s Sask. $n$ to Love.

Nondescript Dagger-Moth - Acronicta spinigera Gn. - Roche Percee and Big Muddy Lake.

Ochre Dagger-Moth - Acronicta morula G. \& R. - Glen Ewen, Roche Percee and Trossachs.

Interrupted Dagger-Moth - Acronicta interrupta Gn. - Maryfield, Roche Percee, Moose Jaw, and Rosefield (se of Val Marie).

Lobelia Dagger-Moth - Acronicta lobeliae Gn. - Tantallon.

Chain-dotted Dagger-Moth - Acronicta fragilis (Gn.) - Central Sask. s to Moose Mountain Park, and Pike Lake; n to Foster Lake; also in Cypress Hills.

? - Acronicta sp. (near A. haesitata (Grt.)) - Tantallon

Unclear Dagger-Moth - Acronicta inclara Sm. - Tantallon.

Powdered Dagger-Moth - Acronicta impleta Wlk. - Central Sask. s to Moose 

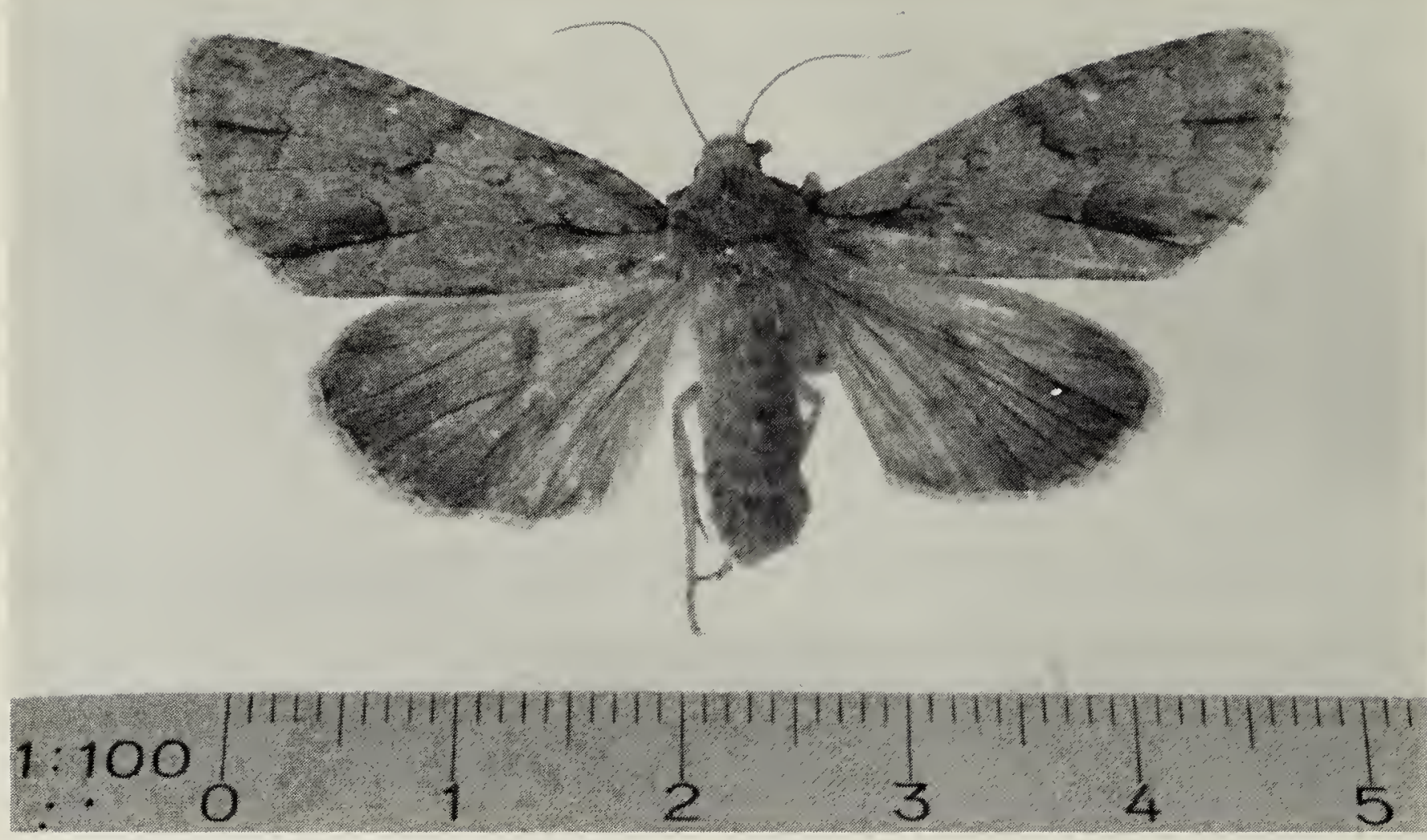

Ochre Dagger-Moth

Ron Hooper

Mountain Prov. Park, Fort Qu'Appelle, and Douglas Prov. Park; n to Weekes, and Meadow Lake Prov. Park. Also in Cypress Hills.

Sperata Dagger-Moth - Acronicta sperata speratina $\mathrm{Sm}$. - s Sask. $\mathrm{n}$ to Hudson Bay and Prince Albert National Park.

Impressa Dagger-Moth - Acronicta impressa Wlk. - s Sask. n to Aylsham.

Distans Dagger-Moth - Acronicta distans (Grt.) - $\mathrm{s}$ Sask. $\mathrm{n}$ to Somme.

Smeared Dagger-Moth - Acronicta oblinita (J.E. Smith) - s Sask. n to Bertwell and Prince Albert.

Pointed Dagger-Moth - Acronicta lanceolaria (Grt.) - Swift Current (Department of Agriculture, Saskatoon); Lumsden (CNC).

Henry's Marsh Moth - Simyra henrici (Grt.) - s Sask. n to Love.

Gem Marvel - Agriopodes geminata (Sm.) - Cumberland House and Pike Lake.

Gray Marvel - Agriopodes teratophora (H.-S.) - s Sask. $n$ to Tantallon, and Pike Lake.

Harris' Three-spot - Harrisimemna trisignata (Wlk.) - Somme and Buffalo Pound Prov. Park.

\section{Expected Species}

Funerary Dagger-Moth - Acronicta funeralis G. \& R. - Eastern Canada w to Manitoba and British Columbia.

Night-wandering Dagger-Moth Acronicta noctivaga Grt. - Eastern Canada w to Manitoba and Oregon.

Long-winged Dagger-Moth - Acronicta longa Gn. - Eastern Canada $w$ to Manitoba and the Rocky Mountains.

Lupine Dagger-Moth - Merolonche lupini (Grt.) - British Columbia e to Malta, Montana.

\section{The Foresters (Agaristinae)}

The foresters are black moths with oblong cream-coloured or white patches on the wings. Our species have bright orange hair on the tibiae of the fore and middle legs. They fly on warm, sunny days along with the butterflies. Our species have clubbed antennae; however, the clubs are longer and more slender than those of butterflies. The caterpillars are usually brightly marked with black and orange and feed on plants of the 

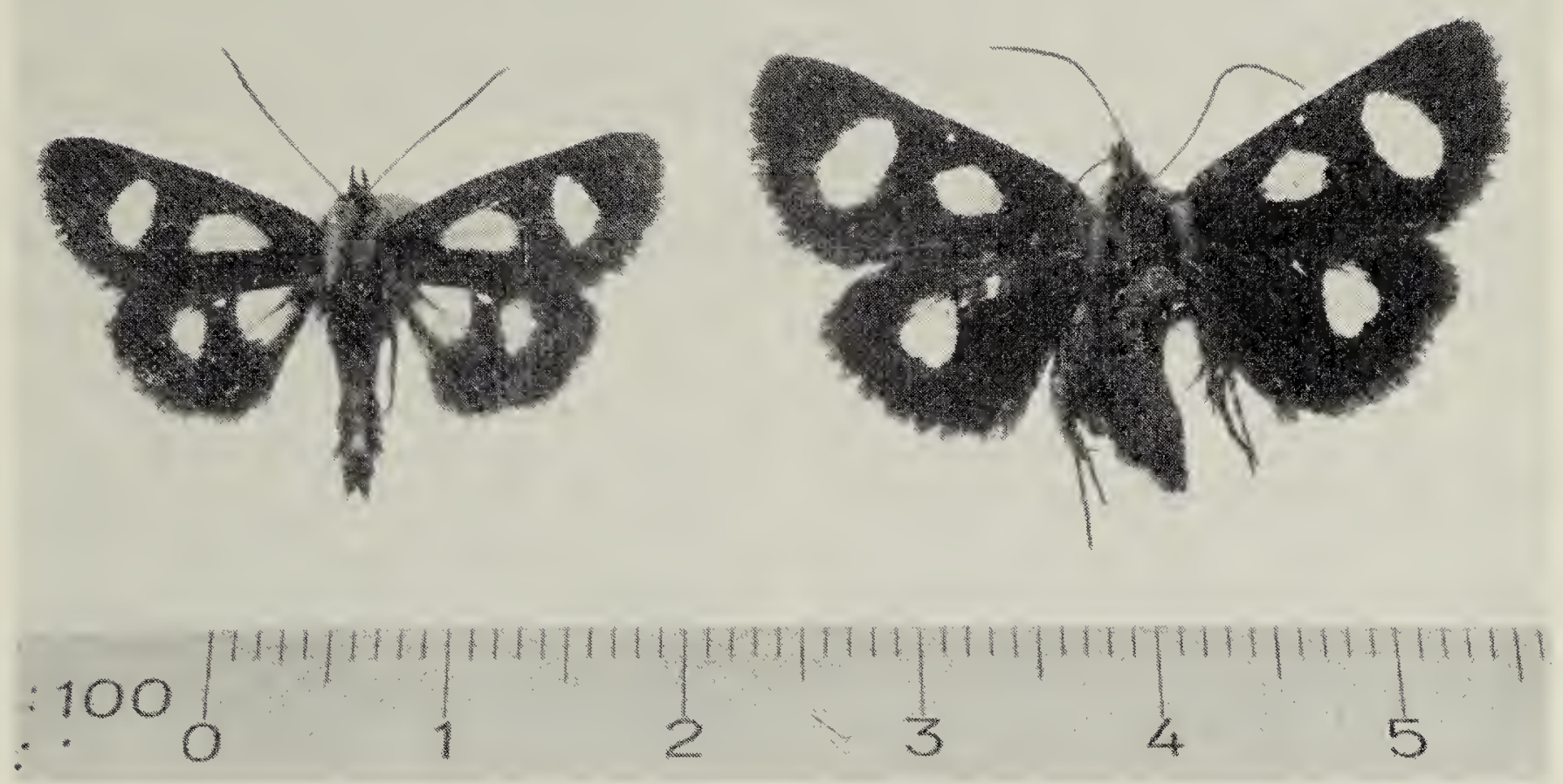

Langton's Forester

Ron Hooper

grape and evening primrose families.

Eight-spotted Forester - Alypia octomaculata (F.) - Regina and Eston.

Langton's Forester - Alypia langtoni Couper - s Sask. $n$ to Milliken Lake ( $\mathrm{s}$ of Uranium City).

Northern Forester - Androloma maccullochii (Kby.) - n Sask. s to Greenbush Campsite ( $w$ of Hudson Bay), La Ronge, and Clearwater River ( $\mathrm{n}$ of La Loche).

\section{Expected Species}

Pearly Wood Nymph - Eudryas unio (Hbn.) - Eastern Canada w to Transcona, Manitoba, and Utah.

1. COOK, WILLIAM E. 1931. An ecologically annotated list of the Phalaenidae of Montana (Lepid.). Canadian Entomologist 63:1-9.

2. MTTCHELL, ROBERT T. and HERBERT S. ZIM. 1964. Butterflies and moths, a guide to the more common American species. Golden Nature Guide.

Whooping Crane distribution as given in the 1895 Checklist of North American Birds (American Ornithologists' Union, New York): "Interior of North America, from the Fur Countries to Florida, Texas, and Mexico, and from Ohio to Colorado. Formerly the Atlantic coast, at least casually, to New England." 